\title{
Defamatory meanings and the hazards of relying on the 'ordinary, reasonable person' fiction
}

\begin{abstract}
Defamation law offers a remedy when the plaintiff's reputation is harmed by something the defendant publishes. At the heart of the action lies the question-what do the words complained about actually mean? The process of determining defamatory meaning depends heavily on what the court finds to be the imputations conveyed by the matter concerned to 'ordinary, reasonable people'. The process relies on assumption and conjecture, rather than on evidence. This article examines how this process applied in the Hockey v Fairfax Media case brought by Australia's former Federal Treasurer Joe Hockey against Fairfax Media, which presented a paradox - the court described the journalists' articles concerned in glowing terms but still found for the plaintiff.
\end{abstract}

Keywords: Asia-Pacific, Australia, convergence, defamation, defamatory imputation, defamatory meaning, defamation reform, digital media, freedom of speech, libel, media freedom, media law, media standards, self-regulation

\section{JOSEPH M. FERNANDEZ}

Curtin University, Perth, Western Australia

\section{Introduction}

-HE REACH of defamation (or libel) law is 'more extensive than many realise' (Rolph, 2015). It is among the 'growing threats to the media across

the Asia-Pacific' (Robie, 2014). The threat of a defamation suit hangs constantly like a Damocles sword over news publishers even though the law is aimed at ensuring no unreasonable limits are placed on freedom of expression and on the discussion of matters of public interest and importance (for example, see Defamation Act 2005 (New South Wales), section 3(b)). The then editor-inchief of The Age, Andrew Holden, whose newspaper was caught up in one of the most well-known Australian defamation cases this decade-Hockey $v$ Fairfax 
Media-described it thus:

The most direct threat we face every day is the operation of our defamation laws. They are being used far too often in an attempt to hinder or shut down journalism. (Bennett, 2015)

The High Court's rulings in a series of free speech cases from September 1992, held that an implied principle of freedom of political communication exists within the Commonwealth Constitution and this is said to have changed the situation 'substantially [and] clearly exemplifies the notion of an "independent" principle of freedom of speech within a legal system' (Chesterman, 2000, p. 3). Through the cases, starting with Nationwide News Pty Ltd v Wills 1992 and Australian Capital Television Pty Ltd v Commonwealth 1992, the court found an implied right in the Constitution to discuss matters of government and politics (Gillooly, 1998, pp. 186-196). The threat of defamation, however, continues to present a direct and constant threat to publishers. Two judgments were handed down in the Hockey $v$ Fairfax Media case, the first on the court's finding on the defamation claim (Hockey $v$ Fairfax Media Publications Pty Limited [2015] FCA 652) and the second on injunctions, interest, costs and the court's orders (Hockey v Fairfax Media Publications Pty Limited (No 2) [2015] FCA 750). Where specific reference is made to one of the two judgments the former is referred to in this work as Hockey $v$ Fairfax Media 2015 and latter is referred to as Hockey $v$ Fairfax (No 2). Unless otherwise stated, when referring to these two cases, the paragraph numbers below refer to the former. The two cases are otherwise collectively referred to as the Hockey Fairfax Media case.

Newsrooms routinely examine contentious material for the threat of defamation. It begins before publication when conducting risk assessments and can arise after publication when a complaint is received. These examinations take into account whether a potential plaintiff can cross the critical threshold for legal action - satisfying the court that the matter concerned (words, images and anything by which meaning is conveyed) does in fact convey the meanings that justify an actionable complaint. Second, the examination weighs up the potential responses to a complaint - an outright denial of the validity of the claims; resolution without litigation; and the availability of a viable defence to the claims. A defamation defendant has no legally imposed duty to respond until and unless the plaintiff is able to meet three elements. These elements are: that the matter complained about is defamatory; it identified the plaintiff as the party to whom the matter relates; and the defendant published the matter (Gillooly, 1998, p. 22). Of the three elements, the first-mentioned element is the most contentious because it requires the identification of the defamatory meanings (or imputations, as lawyers would put it) conveyed by the matter complained about. This has been described as the "first 
ingredient necessary to found' the plaintiff's action (Gillooly, 1998, p. 33). The fortunes of both sides turn heavily on the meaning the court ascribes to the matter concerned. The determination of defamatory meaning heavily influences where the fulcrum is set on the see-saw that balances freedom of expression and the protection of reputation. The Hockey v Fairfax Media case highlights that conundrum. How was liability found in this case, which resulted in major financial cost to both sides, when the journalistic output at the heart of the defamation claim earned the court's praise? For example, the court held that journalist Sean Nicholls' 'research was detailed and not superficial' (para 355). The court also accepted that the manner in which Hockey engaged in political fundraising was 'a matter of public interest' and that the matters in the poster and on Twitter related to his performance of public functions as Treasurer and that it was reasonable for the respondents 'to seek to promote the reading of the articles' (para 242). Despite finding that the tweets were a problem, the court acknowledged the ease with which followers of tweets, by using the hyperlink, may obtain access to the articles themselves (para 208). Furthermore, the plaintiff failed on significant elements of his claim (Hockey $v$ Fairfax Media No 2 2015, paras 46 and 118). What then produced a protracted, high profile trial that came at great cost to both sides? The court stressed that it is 'necessary to keep in mind that the only publication of the $S M H$ found to be defamatory was the poster promoting the articles' (Hockey $v$ Fairfax Media No 2 2015, para 19), while for The Age, Hockey succeeded only in respect of two tweets (Hockey v Fairfax Media No 2 2015, para 2). Fairfax Media in a statement said:

The Court upheld Fairfax's defence of the articles and found them not to be defamatory. Mr Hockey's claims were only upheld in respect to the publication of the SMH poster and two tweets by The Age because they lacked the context of the full articles. No claims were upheld with regard to The Canberra Times. All of Mr Hockey's other claims were dismissed. The judgment included [the statement that] 'much of Mr Hockey's hurt and distress was said by him to result from publications which I have found were not defamatory'. The articles were found to be well researched and accurate. (Hatch, 2015)

The question whether, in the public eye, Hockey's legal action was successful is unlikely to be fully resolved given the variety of indicators for success. The court's view provides a starting point-Hockey had 'partial success' (Hockey $v$ Fairfax Media No 2 2015, para 46). In reality, the action came at considerable cost to both sides - and as the court noted it was the ambit of Hockey's claims that stretched out the trial:

It is improbable that a trial concerning only the $S M H$ poster and the two tweets of The Age would have occupied seven days. Put slightly differently, 
it was the ambit of the claims made by Mr Hockey which defined, and extended, the battleground of the parties' contest. (Hockey v Fairfax No 2 2015, para 103; see also para 105)

Firm figures on the real financial cost to the parties are usually difficult to access but if media reports are any indication each side in this case is estimated to have spent about A $\$ 1$ million on it. The Treasurer could have been left about $\$ 650,000$ out of pocket by the action while the case would have cost Fairfax Media about $\$ 1.35$ million (Jabour, 2015). Hockey only obtained \$200,000 in damages (para 520) and possibly about $\$ 150,000$ in costs going on the overall cost estimate and the court's award of 15 percent of costs (Hockey $v$ Fairfax Media No 2 2015, para 125).

\section{Growing challenge of cross-platform publication}

Intensified cross-platform publishing of news and current affairs content has resulted in major challenges for the regulation of content generally. One of these challenges is the widespread mistaken perception that the law treats non-mainstream media or social media more leniently. In reality, a person is a publisher even when they post on social media and they 'are subject to the same laws as the big media businesses' (Pearson, 2012, xviii). It has been said not even the courts 'know how to handle the huge changes triggered by the internet and social media' (ibid.). The UK's director of public prosecutions conceded the need to filter the tide of potential legal actions social media could unleash upon on the justice system. In its guidelines on prosecuting cases involving communications sent via social media, the DPP observed that if only a small percentage of those millions of social media messages were deemed to be offensive 'there's the potential for very many cases coming before our courts' (Brown, 2012). In guidelines governing prosecutions, the UK prosecutor's office declared that cases that are not considered 'grossly offensive, indecent, obscene or false... will be subject to a high threshold and in many cases a prosecution is unlikely to be in the public interest' (Crown Prosecution Service UK, clauses 12 and 13, emphasis in original). Non-media publishers would be mistaken in taking this as a carte blanche to publish harmful content. In the United States, numerous lower courts have been willing to treat media and non-media defendants 'differently in defamation cases' with the latter enjoying less protection (Stewart, 2013, p. 41).

Despite the growing challenges presented by defamation for cross-platform publishing this area has not received close attention in various reviews involving the media - even though the defamation challenge is mentioned. For example, the Convergence Review Committee was established in early 2011 'to examine the operation of media and communications regulation in Australia and assess its 
effectiveness in achieving appropriate policy objectives for the convergent era' (Convergence Review Final Report, 2012, p. vii). The Committee 'consulted with key industry leaders and organisations, received over 340 written submissions and 28,000 comments' (Convergence Review Final Report, chairman's letter to the minister, Report's introduction). In the Committee's 176-page Final Report, however, the term defamation itself is mentioned twice but only in passing. The review's scant treatment of defamation appears to have been influenced by the Committee's focus on media 'standards' governed through 'self-regulation' generally rather than on media laws impacting on content. Another media inquiry resulting in the Finkelstein Report discusses defamation in more detail (Finkelstein, 2012, pp. 147-152). It refers to defamation as the 'obvious example' of restrictions on speech through private action and notes that many media outlets consider the law of defamation a check on journalistic practice (Finkelstein, 2012, p. 147). The report, however, cites instances that suggest 'defamation is not an effective check on journalistic excesses' (p. 151, emphasis added). More recently, a report by an NGO, Human Rights Law Centre, failed to make a single mention of defamation even though the report observes that the "exercise of our democratic rights to free speech is a "critical part" of checks and balances on government' (Human Rights Law Centre, 2016, p. 5). Likewise, defamation is also not discussed in any detail in the Australian Law Reform Commission's review of laws that encroach on traditional rights and freedoms, even though it is identified as part of 'laws that interfere with freedom of speech' (Australian Law Reform Commission Report, 2015, Chapter 4, footnote 76). This scant treatment is because defamation is not considered a Commonwealth law, which was the ALRC's concern (ibid.). It did not stop the Attorney-General predicting that this report would come to be seen as 'one of the most important reports the Australian Law Reform Commission has ever authored' (Brandis, 2016). The Hockey v Fairfax Media case decision drew fresh calls for defamation reform. For example, the chair of the Australian Press Council, Professor David Weisbrot, said:

If we are serious about free speech and freedom of the press in Australia, then we must tackle defamation law reform as a high priority. The current law seriously inhibits investigative reporting and robust political debate and, make no mistake, politicians of all stripes are heavy users of defamation writs (Weisbrot, 2015).

Defamation law is fertile for reform. In Australia the last major reform in the middle of the last decade resulted in the introduction of uniform defamation law. No serious effort aimed at defamation law reform has been made since then even though the calls for reform have persisted. It is outside the scope of this article to discuss defamation law reform in general. It is hoped, however, that the discussion below will serve to inform any reform debate pertaining 
to the most critical of the three elements necessary to found a defamation action - the establishment of the existence of defamatory meaning. It does this by drawing attention to the artificiality and arbitrariness that infests this critical aspect of a defamation action by reference to the Hockey $v$ Fairfax Media case.

\section{Background to the Hockey v Fairfax Media case}

Former Federal Treasurer Joe Hockey sued Fairfax Media publications over defamatory imputations conveyed by articles published in The Sydney Morning Herald (the SMH), The Age and The Canberra Times (referred to as 'respondents' in this article). The articles said he was providing 'privileged access' to a 'select group' in return for donations to the Liberal Party via a 'secretive' fundraising body, the North Sydney Forum, whose activities were not disclosed fully to election funding authorities (para 2). These media outlets also published articles on their online platforms, or provided links to articles with content similar to the printed articles and some were tweets and one was a poster or a placard (paras $3-4 ; 12-61)$. The tweets and the poster are the critical platforms as they contained the words Treasurer for Sale or Treasurer Hockey for Sale (tweets); and Treasurer for Sale (poster). The three actions were heard together. Hockey claimed the articles and the $S M H$ poster conveyed some or all of the imputations that he: (a) accepted bribes to influence his decisions as Treasurer (primary imputation); (b) was prepared to accept bribes (in the alternative to (a)); (c) corruptly solicited payments (in the alternative to (a)); (d) he is corrupt (alternatives to (b) and (c)); (e) he corruptly sells privileged access to himself to a select group (only re some articles; alternatives to (b) and (c); ultimately this imputation was at forefront of his submissions); (f) he knowingly permitted a Liberal Party fundraising forum he was associated, to accept money from the corrupt Obeid family (alternatives to (b) and (c); paras 5 and 6).

The court found that at the forefront of Hockey's submissions was the imputation that he corruptly sold 'privileged access' to himself to a select group 'in return for donations to the Liberal Party' (paras 5 and 6). The court upheld $\mathrm{Mr}$ Hockey's claims only with respect to the $S M H$ poster and two tweets published by The Age while each of the remaining claims failed (paras 10 and 214). It held that the respondents did not make out the defence of qualified privilege and even if this defence were otherwise available, it would have been defeated in the case of the $S M H$ articles and the $S M H$ poster on the grounds of malice (para 10). The court awarded damages of $\$ 120,000$ and $\$ 80,000$, respectively, in relation to those claims (para 520). The court dismissed Hockey's claims with respect to the other publications that he complained about (para 521).

\section{A critical threshold-what is defamatory?}

An established defamation text cites the difficulty of producing a comprehensive 
definition of the meaning of defamatory and notes that this difficulty has 'often been remarked' (Milmo \& Rogers, 2008, p. 37). Lord Lyndhurst LC, appointed in 1843 to consider the law of defamation, was not able to 'hit upon anything like a definition of libel which possessed the requisites of a logical definition' (ibid.). The meaning of the matter complained about is determined by reference to a hypothetical referee commonly referred to as the ordinary person or ordinary, reasonable person. These two expressions are themselves problematic because the terms ordinary and reasonable have different properties and 'variations frequently appear in the case law' (Baker, 2011, p. 35). Furthermore, the determination depends heavily on speculation. In Hockey v Fairfax Media 2015, White J states:

In determining what is reasonable in any case, a distinction must be drawn between what ordinary reasonable readers (drawing on their own knowledge and experience of human affairs) could understand from what the publisher has said in the matter and the conclusion which the readers could reach by taking into account their own beliefs which have been excited by what was published. It is the former, and not the latter, which is pertinent (para 69, emphasis added).

A noted defamation list judge once observed that the amount of the Court's time and litigants' resources expended in determining what words mean is 'positively scandalous (John Fairfax Publications v Gacic 2007, para 193 n 175). The potpourri of case law formulations of ordinary, reasonable persons is bogged in verbiage. The formulations include those who can and do 'read between the lines in the light of [their] own general knowledge and experience of worldly affairs' (Lewis v Daily Telegraph 1964, p. 258); and those who do not 'live in an ivory tower [and are] not inhibited by a knowledge of the rules of construction' (Lewis $v$ Daily Telegraph 1964, p. 258). Notwithstanding that the objective of the exercise is to identify the ordinary, reasonable person, the construct of this hypothetical individual has been said to even allow for 'a certain amount of loose thinking' (Morgan v Odhams Press 1971, p. 1245); and may admit 'far-fetched inferences' (Morgan v Odhams Press 1971, p. 1244). As White J said above, the court must decide what this community 'could understand' from what the publisher said; it must decide what conclusion the readers 'could reach'; it must take into account the reader's 'own beliefs' that were excited by what was published; and ultimately what is 'pertinent' is not what the publisher has said, but rather, what the hypothetical reader understood (para 69). As noted above also, a range of terms connoting assumption and conjecture bear heavily on identifying the audience in whose eyes the complainant's esteem is perceived. Of relevance for present purposes is the extent of assumption and conjecture in respect of determining the imputations conveyed. The term imputation is, on the one hand, said to refer to any act or condition attributed to a person, regardless of whether it is to that 
person's credit or discredit (Hall-Gibbs Mercantile Agency v Dun 1910, p. 91). On the other hand, the term is said to carry a disparaging sense (Petritsis $v$ Hellenic Herald Pty Ltd 1978, p. 189). Whether the various characterisations of the hypothetical referee remain relevant is open to question in light of recent High Court authorities (Rolph, 2016, p. 99).

A substantial part of the Justice White's judgment discussed the imputations conveyed across the different publications and platforms. They covered 152 paragraphs (paras 62-214) of the 522-paragraph judgment. Determining the imputations conveyed is critical in deciding whether defamation has occurred. Lord Devlin said one 'always gets back to the fundamental question: what is the meaning of the words conveyed to the ordinary man' (Lewis $v$ Daily Telegraph 1964, p. 285). A single judge, with no jury, heard the Hockey v Fairfax Media case and the judge assumed the jury's role in evaluating the claims of defamatory imputations conveyed. The core principles governing the question-whether the publications conveyed the pleaded imputations - are taken by the courts as settled in numerous authorities. The primary question or test is 'whether ordinary reasonable readers would have understood the matters complained of in the defamatory senses pleaded' (para 63). The test, however, is widely acknowledged to be fraught with difficulty. The various descriptions of what constitutes the ordinary, reasonable person 'when viewed collectively, hardly present a coherent picture of the hypothetical audience that determines what is defamatory' (Baker, 2011, p. 47). The list of characteristics ascribed to such a person is long, and it includes taking into account the possibility that readers may engage in some 'loose thinking'; and that readers are of 'ordinary intelligence, experience and education, who are neither perverse nor morbid nor suspicious of mind, nor avid for scandal (paras 63-64). This approach to determining the question of imputations conveyed has long troubled defamation defendants. It is a major concern when a publication is found to have conveyed an imputation that was not in the publisher's contemplation. Former High Court judge Justice Michael Kirby has advocated dropping the almost ludicrous elaborations of the characteristics of the hypothetical referee with judges and juries being frankly responsible for the decisions they make (Rolph, 2016, p. 100). In Favell v Queensland Newspapers Pty Ltd 2005, Kirby J said:

It would be preferable to drop this fiction altogether. Judges should not hide behind their pretended reliance on the fictitious reasonable recipient of the alleged defamatory material, attributing to such a person the outcome that the judges actually determine for themselves. (para 24)

In the Hockey $v$ Fairfax Media 2015 case, White J found that the SMH poster and two matters published on Twitter by The Age with the words 'Treasurer for Sale' and 'Treasurer Hockey for Sale' defamed Hockey but that Hockey's 
remaining claims were not established (paras 10-11 and 214). The respondents denied all the imputations (para 7). They acknowledged, however, that if the publications conveyed the claimed meanings they were defamatory. The contest between the parties in respect of the imputations was whether the publications did convey the pleaded imputations (para 62).

The difficulty of determining what imputations are conveyed is well acknowledged. Lord Devlin wrote- ' what is the meaning of the words conveyed to the ordinary man-you cannot make a rule about that' (Lewis v Daily Telegraph 1964 , p. 285). Defamation law's unique approach to language invests the court with the power to proclaim a single meaning to words or phrases complained about. Given that words can reasonably mean different things to different people 'this reductive approach to language contributes to the artificiality of the tort' (Rolph, 2015). Baker, in his discussion of the realist/moralist debate afflicting defamation notes:

Herein lies what for me is the great ambiguity of defamation law: the
comparative role of moral and social standards. Put at its simplest the
question is this: does defamation depend on what people $d o$ think, or what
they should think? Or does it rely on some combination of the two. (2011,
p. 10, emphasis in original)

This presents a serious predicament for publishers as it exposes them to the mercy and the idiosyncrasies of the tribunal. Justice Levine once observed that in the law's quest to give claimants a remedy heed must be paid to the 'real world':

There is a risk that 'real world' will be forgotten when in pursuit of a remedy for the grievance all attention is focused on the artificial construct of the imputation to the exclusion of the published material which conveyed it (Sutherland v ACP Publishing 2000, para 20).

What then constitutes the 'real world' and by what measure is the 'real world' determined? How did the court in the Hockey $v$ Fairfax Media case address the 'real world' imperative when determining the imputations conveyed? As seen below these answers to these questions were heavily reliant on the judge's own assumptions rather than on evidence pointing to the 'real world'.

\section{Ordinary, reasonable person and assumptions}

The ordinary, reasonable person test, which lies at the heart of a defamation inquiry, represents a test by which the court purports to affix imputations to the matter complained about. It does so by resorting to various assumptions, for example, that it is possible to identify with some certainty the hypothetical referee through whose eyes defamation has occurred. The determination 
of the harmful imputations thereafter goes on to impact on how the defendant responds. A defendant might be left with having to defend the truth of words not used in the article complained about but from which imputations are said to arise. The process of determining what imputations are conveyed generally requires the suspension of a hallowed feature of a court process - the need for evidence in relation to the claims made. The term evidence in its ordinary legal sense means '[a]ny object or information, other than legal submissions, which tends to prove or disprove the existence of a fact in issue' (Finkelstein and Hamer, 2015, p. 235). This may be described as the 'strict sense' of the term as it turns on proof. There are three primary forms of evidence: testimony, documents and real evidence; and evidence is also subject to other classifications, that take a looser approach-for example, direct and circumstantial; oral, documentary and real; original and derivative; primary and secondary; expert and lay; sworn and unsworn; and admissible and inadmissible (Finkelstein \& Hamer, 2015, p. 235).

The term evidence appears 125 times in the judgment, for example, in referring to what the 'evidence indicates' (paras 185, 246, 426, 438, 456 and 469). For example, White $\mathrm{J}$ refers to what the evidence indicated when discussing a newspaper staff member's consideration of whether the poster might convey a meaning different from that conveyed by the news articles (para 246). In relation to meaning, however, the rules concerning evidence on meanings are:

No evidence of recipients' understandings is admissible on natural and ordinary meaning, which is a 'curiosity of defamation law'. Neither dictionary definitions nor readership surveys are admissible....Evidence would usurp the jury function to use the objective test of the ordinary, reasonable recipient. (Kenyon, 2006, p. 26, references omitted).

Thus, when it comes to the determination of the imputations conveyed, the court resorts heavily to assumption, conjecture, the use of imprecise and speculative terms and general arbitrariness. As a result, subjectivity is deliberately injected and methodological rigour is replaced by 'conjecture and iniquity' (Baker \& Leslie, 2008, p. 422). For convenience we may collectively describe these as assumptive terms as they turn heavily on assumption, conjecture, imprecision, speculation and general arbitrariness. These terms are not grounded in evidence in the sense of being '[a]ny object or information, other than legal submissions, which tends to prove or disprove the existence of a fact in issue' (Finkelstein $\&$ Hamer, 2015, p. 235). The use of the assumptive device highlights another paradox in a defamation action - the role of evidence, a cornerstone of any trial process. In the present case, evidence was not an alien feature as illustrated by White J's reference to it: 
If the Court may take these matters into account, the parties should be permitted to adduce evidence bearing on them. A defendant, in particular, should be able to put material before a court bearing upon its consideration of the matters enumerated ... (para 330).

The next section considers the various assumptive terms used in the Hockey $v$ Fairfax Media case with a focus on two such terms - 'likely/unlikely' and 'may'.

\section{Court's heavy reliance on conjecture and assumption}

A count of the various assumptive terms in the Hockey v Fairfax Media 2015 case shows the term 'would' was used 194 times, including in the context 'would have' and 'would not have'. Other such assumptive terms are: 'could' (46 times); 'some' (94); 'relatively few' (154); 'many' (29); 'it is possible' (4); 'I think' (7); 'suggests' (8); 'likely/unlikely' (29); and 'may', including twice as 'may possibly' (96). This article examines these latter two terms-'likely/ unlikely' and 'may' - in more detail.

\section{Use of the term 'likely/unlikely'}

The common dictionary meaning for 'likely' is 'such as well might happen or be true; probable' (Oxford Dictionaries Online). 'Unlikely' is the opposite of 'likely'. It clearly does not mean 'certainly' while the term 'might' in that dictionary definition begs the question whether it also 'might not' although common usage suggests that the meaning leans to the former. The point for present purposes is the looseness of the term and the bearing it can have on the parties' fortunes in a case. The term 'likely' or 'unlikely' is used on 29 occasions in the judgment. Of these 29 occasions the term can be said to have been used in reference to 'meaning' on 15 occasions (paras 67, 89, 115, 120, 123, 131, 141, 151, $154,168,208,478$ ) while the remaining uses do not directly pertain to 'meaning'. An example of when the term is not used directly in relation to 'meaning' is when White J, uses the term to refer to a date when a certain event was 'likely to have' occurred (para 185). An example of the use of the term 'likely'(and 'may', which is discussed in more detail below), to form a view as to the meaning understood by ordinary, reasonable people can be seen in the following:

Against this background, I consider that some readers may reasonably have understood some of the initial passages in the $S M H$ printed articles to be stating that Mr Hockey was making improper use of his important office as Treasurer by agreeing to see persons if they made a contribution to his own campaign funds or to the Liberal Party. They are likely to have understood from these particular paragraphs that the $S M H$ was indicating that Mr Hockey was engaged in a form of corrupt conduct. (para 120, emphasis added) 
Thus, the terms are used to draw a conclusion as to what the reader understood. It is not suggested that every such resort to such terms is disadvantageous to the respondent, as can be seen here:

As with the $S M H$, ordinary reasonable readers are likely to have understood The Age to be reporting that Mr Hockey was engaging in a form of commonly accepted political fundraising, although in circumstances involving a number of features which The Age considered undesirable. For the reasons given earlier, they are not likely to have regarded this form of political fundraising as corrupt. (para 151, emphasis added)

The availability of two contrasting positions illustrated above invests significant discretion in the hands of the court to pick a position that impacts unfavourably on one party or the other. It can turn the process of determining defamatory imputations into a lottery.

\section{Use of the term 'may'}

The second term in the judgment for a similar examination as above is 'may'. The term permits a variety of meanings - 'expressing possibility, permission, wish, uncertainty' (Godfrey-Smith et al, 1991, p. 487). It is often contrasted with 'shall' (Finkelstein \& Hamer, 2015, p. 401). The term is used 96 times in its assumptive sense in the judgment. Of these, on 41 occasions it was used in the course of citing authority, principles, news articles, testimony or submissions. Fourteen of the 96 uses are deemed not relevant for the purposes of the present analysis and are thus excluded. Two examples of such exclusion on the grounds of irrelevance are when the court observed that a certain article 'may also have been published on the websites' (para 187); and when the court observed that a certain aspect of the hearing 'may have had the effect of disrupting Mr Hockey's cross-examination' (para 323). These uses clearly do not go directly to the present argument concerning assumptions about imputations. Of primary concern for present purposes are the remaining 41 occasions that can be broadly described as uses when White $\mathrm{J}$ expressed his own opinion on a particular point. Of these 41 occasions, the use of 'may' on 34 occasions was closely connected to the question of imputations - in some instances more directly than in others (paras $89,90,92,115,116,120,120,121,121,122,125,139$, $143,163,166,201,202,202,202,202$ ('may' used twice in the same sentence), $207,207,207,208,241,243,246,317,358,359,359,445,481,481)$. It is not suggested here that there is no room at all for using the term in an assumptive sense in a defamation judgment. It is argued, rather, that the use of such an assumptive term would be more acceptable if it entailed a consideration of some form of evidence, whether in the strict sense referred to above, or otherwise.

For illustration purposes, let us consider examples each of the two types of 
uses of the assumptive term 'may'. First, the use of the word in the context of determining whether a defamatory imputation was conveyed, where no evidence is provided and where the opinion expressed is akin to a straight out assumption. Three examples of this are provided here, of which one is discussed in detail. First, the judge acknowledged the respondent's submission that the ordinary, reasonable reader would recognise that the poster was not 'telling or purporting to tell them the whole story' (paras 165-166). The judge found that the poster may have this effect but that it would be inappropriate to limit the effect in this way (para 166). The judge goes on to hold that the poster "would have been understood by ordinary reasonable readers as conveying assertions of fact, in particular, that the $S M H$ had carried out an investigation which had revealed matters indicating that Mr Hockey was "for sale"' (para 167). Second, the judge said, "[s]ome may read the tweet without going further' than the hyperlink provided (para 207). A third instance of this type of use of the term 'may' is examined next in more detail. White J said:

I consider that the heightened consciousness, to which I have just referred is part of the context in which the understanding of the ordinary reasonable reader of the SMH articles is to be assessed because, by reason of these events, the ordinary reasonable reader may have been more ready to understand the SMH articles as conveying an imputation of corruption. (para 92, emphasis added)

This statement bears further examination. Where is the evidence of this 'heightened consciousness'? The judge says he 'referred' to it. That reference apparently occurs two paragraphs earlier where he stated:

Another relevant circumstance is that the $S M H$ articles were published at a time when it can be taken that there was a heightened consciousness in New South Wales in particular about corruption arising from the receipt of benefits by public officials from persons who may benefit from their decisions. (para 90, emphasis added).

This statement, however, does not provide the requisite evidence of the heightened consciousness of a kind that sustains Hockey's claim in defamation. As argued below, the status of the New South Wales corruption watchdog, the Independent Commission Against Corruption, as an arbiter of corrupt behaviour has been in question for some time. The judge, however, assumes that there was a heightened consciousness about corruption and proceeds on the basis that 'it can be taken' as such (para 90). He declares this to be another relevant circumstance in the 'ascertainment of the meaning which the $S M H$ printed articles conveyed to ordinary reasonable readers' (para 89). An important question arises - why is that 'a 
relevant circumstance' in the present context? Could it be because anyone caught up in an ICAC process becomes tainted in the public eye even though they might be blameless? Evidence given at ICAC hearings have been said to impute guilt even though it is not a court of law but 'merely an agency of the executive branch of government' (Merritt, 2015). The ICAC has been likened to 'an unaccountable star chamber in need of reform' and it has been seen as conducting 'show trials for the media' (Albrechtsen, 2014). The Media Alliance has referred to the ICAC as a 'star chamber' (Media Alliance, 2015, p. 46). A former commissioner of the ICAC and former judge of the New South Wales Court of Appeal Jerrold Cripps has said that although the ICAC is not a criminal law enforcement agency, it 'behaves if it were a branch of the police force' (Cripps, 2013). More recently his successor observed in a written report that if the ICAC is to be taken seriously it 'must not be perceived as an institution culturally projecting an almost breathtaking arrogance' (Office of the Inspector of the ICAC, p. 1).

\section{Conclusion}

More than a decade ago Justice Kirby advocated 'a different approach' in determining imputations - one that would move 'away from fictions and in the direction of substance and reality' (Favell v Queensland Newspapers Pty Ltd 2005, para 26). His Honour said that, however, was 'not the occasion' to explore a new approach (ibid.). The invitation to explore a new approach remains open. As Baker and Leslie stated:

[W] e should not readily resign ourselves to administering justice on the basis of mere conjecture as to the way people read and respond to the publications they encounter. (2008, p. 445).

The Hockey v Fairfax Media case presented an opportunity to reflect the move away from fictions and more squarely acknowledge real world imperatives. Among such imperatives, are the media's growing resort to cross-platform publication; the ability of ordinary, reasonable audiences to recognise social media as a platform for trenchant and often exaggerated exchanges; and the capacity of such audiences to sift fact from the puffery of advertising posters. In accepting that the sparse words in two tweets and a poster-all clearly pointing to detailed articles which themselves were of sound journalistic quality - were sufficient to find in favour of the plaintiff, the court sent chill winds through journalism. Defamation law has long been recognised as a key source of the 'chilling effect' on speech and this effect is more pronounced against a backdrop in which freedom of speech is a residual or secondary liberty - it is what is left over after legislation and the creeping amendments of the common law have taken effect (Magnusson, 2001, p. 297). This is exacerbated by contemporary challenges facing the media: 
At a time when the rivers of gold have disappeared for traditional media, the number of aggressive defamation actions has increased. The judiciary has added to the confusion. (Bartlett, 2015, p. 14)

The Hockey $v$ Fairfax Media case construed the imputations conveyed by the poster and tweets in a manner that was unduly unfavourable to the media respondents although in practical terms the outcome was only a pyrrhic victory for the plaintiff. Legislative and judicial lethargy in introducing reform continues to leave the media vulnerable. For publishers, many important lessons arise from the Hockey $v$ Fairfax Media case but for present purposes the following six suffice. They are set out here in no particular order and are not necessarily discrete in the concerns that they address. First, the determination of defamatory imputations turns heavily on fortunes akin to a lottery. Much depends on what the hypothetical referee is deemed to make of the matter complained about and the circumstances of individual cases. Publishers must remain alert to the vagaries afflicting the determination of defamatory imputations. Second, publishers must avoid speaking loosely about smoke so as to avoid any suggestion that there is a fire if there is no fire. As noted in Lewis v Daily Telegraph 1964 it 'can be done' (p. 285). The Hockey v Fairfax Media case showed the perils of taking journalistic liberties with tweets, poster texts and banner headlines. As noted above, however, the plaintiff's victory came in spite of the court's recognition of much in Fairfax Media's favour and that the claim 'possibly, may not have involved a trial at all' (Hockey v Fairfax Media (No 2) 2015, para 118; Fernandez, 2016, pp. 46-47). Third, while there may be grounds to assume that the law is unable to keep up with regulating non-traditional media platforms or that such platforms enjoy a looser standard, the Hockey v Fairfax Media case reminds us that such platforms cannot escape the vortex of liability. Fourth, proof of malice has a debilitating effect on a defamation defence. Defendants should avoid fuelling any basis for such claims when preparing matter for publication. Fifth, while defamation law provides a range of defences the fact that the threshold for suing is set rather low means defendants are susceptible to being dragged to court. That puts an undue burden on prospective defendants. Unless the threshold for suing is raised, for example by placing additional burdens especially on 'public figure' plaintiffs, publishers must proceed with caution. Sixth, defamation law has long suffered a tarnished reputation in publishers' eyes. Reform thus far has gone not much further than tinkering around the edges. At the time of this writing Oxford Dictionaries named the word 'posttruth' - word of the year. It means 'relating to or denoting circumstances in which objective facts are less influential in shaping public opinion than appeals to emotion and personal belief' (Oxford Dictionaries Online). It has been suggested that 'doublespeak' is a feature of the post-truth world (Fine, 2016). The 
post-truth world has the potential to alter the way defamatory imputations are settled but that discussion is for another occasion. For now, the calls for defamation law reform prompted by the Hockey $v$ Fairfax Media case must translate into action. Media groups should lead reform initiatives as they are better placed than most to press for reform. And they have more at stake than most.

\section{References}

Albrechtsen, J. (2014, November 12). Parliament must curb power-hungry ICAC. The Australian. Retrieved February 7, 2016, from www.theaustralian.com.au/opinion/ columnists/parliament-must-curb-powerhungry-icac/story-e6frg7bo-1227119906023

Australian Law Reform Commission. (2015, December). Traditional rights and freedoms - encroachments by Commonwealth laws. Final Report No 129.

Baker, R. (2011). Defamation law and social attitudes: Ordinary unreasonable people. Cheltenham, UK: Edward Elgar.

Baker, R. \& Leslie, J. (2008). Rethinking the defamation jury. Media and Arts Law Review, 13, 422-446.

Bartlett, P. (2015). The Year in Australian Media Law. Going after whistleblowers, going after journalism. The report into the state of press freedom in Australia in 2015. Sydney, NSW: Media Arts and Entertainment Alliance (MEAA) .

Bennett, L. (2015, September 30). Publishers back calls for metadata law review. The Newspaper Works. Retrieved from www.thenewspaperworks.com.au/publishers-backcalls-for-metadata-law-review/

Brandis, G. (2016, March 2). Address at the launch of the Australian Law Reform Commission Report on Traditional Rights and Freedoms. Retrieved from www. attorneygeneral.gov.au/Speeches/Pages/2016/FirstQuarter/2-March-2016-Addressat-the-launch-of-the-Australian-Law-Reform-Commission-Report-on-TraditionalRights-and-Freedoms.aspx

Brown, R. (2012, December 20). British courts allowed to go easy on offensive tweets. $A B C$ News. Retrieved January 30, 2016, from http://www.abc.net.au/news/2012-1220/british-courts-issued-new-social-media-guidelines/4437812

Chesterman, M. (2000). Freedom of speech in Australian law: A delicate plate. Aldershot, UK: Dartmouth.

Convergence Review Final Report. (2012, March). Department of Broadband, Communications and the Digital Economy.

Cripps, J. (2013, August 30). ICAC should stick to charter. The Australian. Retrieved February 7, 2016, from www.theaustralian.com.au/business/legal-affairs/icac-shouldstick-to-charter/story-e6frg97x-1226706943429

Crown Prosecution Service UK. (n.d.) Guidelines on prosecuting cases involving communications sent via social media. Retrieved January 30, 2016 from www.cps.gov. uk/legal/a_to_c/communications_sent_via_social_media/

Fernandez, J.M. (2016). The Hockey case. In Media, Entertainment and Arts Alliance Press Freedom Report, Criminalising the truth - suppressing the right to know: The report into the state of press freedom in Australia in 2016 (pp. 46-47). Sydney, NSW: Media Alliance. Retrieved from https://pressfreedom.org.au/the-hockey-casefc568e4546bd\#.edl6fjv60

Fine, D. (2016, November 18). Colourful days ahead in post-truth world. The Age, 
p. 19. Retrieved November 20, 2016, from http://search.proquest.com.dbgw.lis.curtin. edu.au/docview/1840691076/fulltext/FAF3A949375E4623PQ/1?accountid=10382

Finkelstein, R. (2012, February 28). Report of the independent inquiry into the media and media regulation.

Finkelstein, R. \& Hamer, D. (2015). LexisNexis concise Australian legal dictionary $5^{\text {th }}$ Ed.] Chatswood, NSW: LexisNexis Butterworths.

Gillooly, M. (1998). The law of defamation in Australia and New Zealand. Leichardt, NSW: Federation Press.

Godfrey-Smith, A., Williams, J.H., Hughes, J., Purchase, S. \& Ramson, W. S. (1991). The Australian reference dictionary. Oxford, UK: OUP.

Hatch, B. (2015, June 30). Judgment says Fairfax Hockey articles were not defamatory, [Media Release]. Sydney: Fairfax Media

Human Rights Law Centre. (2016, February). Safeguarding democracy [Report]. Melbourne: HRLC. Retrieved February 24, 2016, from http://hrlc.org.au/wp-content/ uploads/2016/02/HRLC_Report_SafeguardingDemocracy_online.pdf

Jabour, B. (2015, 22 July). 'Treasurer for sale' defamation case: Fairfax must pay $15 \%$ of Hockey's costs. The Guardian. Retrieved February 5, 2016, from www.theguardian. com/australia-news/2015/jul/22/treasurer-for-sale-defamation-case-fairfax-must-pay15-of-hockeys-costs

Kenyon, A. T. (2006). Defamation comparative law and practice. Oxon, UK: UCL Press.

Magnusson, R. S. (2001). Freedom of speech in Australian defamation law: Ridicule, satire and other challenges. Torts Law Journal, 9, 269-272.

Media Alliance. (2015). Star chamber. Going after whistleblowers, going after journalism. Report into the State of Press Freedom in Australia in 2015.

Merritt, C. (2015, November 6). When mud sticks... cost of ICAC's rough justice. The Australian. Retrieved February 7, 2016, from www.theaustralian.com.au/business/legalaffairs/when-mud-sticks-cost-of-icacs-rough-justice/story-e6frg97x-1227598020693

Milmo, P. \& Rogers, W.V.H. (2008). Gatley on libel and slander [11 ${ }^{\text {th }}$ ed.] London, UK: Thomson Reuters.

Office of the Inspector of the Independent Commission Against Corruption. (2015). Annual Report 2014-2015.

Oxford Dictionaries Online.

'likely': Retrieved July 22, 2016, from www.oxforddictionaries.com/definition/english/likely

'post-truth': Retrieved November 20, 2016, from https://en.oxforddictionaries.com/ definition/post-truth

Pearson, M. (2012). Blogging \& tweeting without getting sued. Sydney, NSW: Allen \& Unwin.

Robie, D. (2014, May 3). E-libel laws the new front line in Pacific battle for press freedom. The Conversation. Retrieved July 23, 2016, from https://theconversation. com/e-libel-laws-the-new-front-line-in-pacific-battle-for-press-freedom-25611

Rolph, D.

- (2016). Defamation law. Pyrmont, NSW: Lawbook Co.

- (2015, November 27). Our defamation law needs basic overhaul. The Australian. Retrieved February 5, 2016 from www.theaustralian.com.au/business/legal-affairs/ david-rolph-defamation-law-needs-fundamental-reform/news-story/bff7b6ee531c$535 \mathrm{c} 68 \mathrm{f} 4 \mathrm{c} 271 \mathrm{f} 1 \mathrm{ffdc} 14$

Stewart, D. (2013). Social media and the law: A guidebook for communication students and professionals. New York, NY: Routledge. 
Weisbrot, D. (2015, July 1). Australian Press Council chair calls for urgent action on defamation law reform. [Media Release]. Sydney, NSW: Australian Press Council.

\section{Legislation}

Defamation Act 2005 (New South Wales).

\section{Cases}

Australian Capital Television Pty Ltd v Commonwealth (1992) 177 CLR 106.

Favell v Queensland Newspapers Pty Ltd [2005] HCA 52.

Hall-Gibbs Mercantile Agency Ltd v Dun (1910) 12 CLR 84.

Hockey v Fairfax Media Publications Pty Limited [2015] FCA 652.

Hockey v Fairfax Media Publications Pty Limited (No 2) [2015] FCA 750.

John Fairfax Publications Pty Ltd v Gacic [2007] HCA 28.

Lewis v Daily Telegraph Ltd [1964] AC 234.

Morgan v Odhams Press Ltd [1971] 1 WLR 1239.

Nationwide News Pty Ltd v Wills (1992) 177 CLR 1.

Petritsis v Hellenic Herald Pty Ltd (1978) 2 NSWLR 174.

Sutherland v ACP Publishing Pty Ltd [2000] NSWSC 1139.

Associate Professor Fernandez is the head of Curtin University's Journalism Department and teaches media law. He is the author of Media Law in Australia: Principles, Pitfalls and Potentials (2014). Dr Fernandez is the former chief editor of a Malaysian daily newspaper and has been a defendant in defamation actions. His research interests focus on the areas in which the law and journalism intersect. His PhD in defamation law proposed a loosening of the defence of truth for media defendants in defined circumstances. His other research interests include legal protection for journalists' confidential sources and privacy. He tweets from DrJM_Fernandez. This article is developed from the author's presentation entitled 'Convergent journalism and defamation pitfalls: Lessons from Hockey $v$ Fairfax 2015' at the Journalism Education and Research Association of Australia 2015 Conference, Dangerous Journalism, Bathurst, New South Wales, 30 November-2 December 2015. The author is grateful to the referees for their very helpful comments. j.fernandez@curtin.edu.au 